\title{
Spreadsheet Description Document for Saturation Temperature Calculation
}

J. Jo

CH2M HILL Hanford Group, Inc.

Richland, WA 99352

U.S. Department of Energy Contract DE-AC27-99RL14047

$\begin{array}{lll}\text { EDT/ECN: } & \text { NA } & \text { UC: NA } \\ \text { Cost Center: } & \text { 7T600 } & \text { Charge Code: } 502298 \\ \text { B\&R Code: } & \text { NA } & \text { Total Pages: } 9\end{array}$

Key Words: Saturation, Temperature,WCA, Pressure, Waste

Abstract: This document describes the methodology for determining the saturation temperature in waste tanks. The saturation temperature is used to calculate neutral buoyancy ratio.

TRADEMARK DISCLAIMER. Reference herein to any specific commercial product, process, or service by trade name, trademark, manufacturer, or otherwise, does not necessarily constitute or imply its endorsement, recommendation, or favoring by the United States Government or any agency thereof or its contractors or subcontractors.

Printed in the United States of America. To obtain copies of this document, contact: Document Control Services, P.O. Box 950, Mailstop H6-08, Richland WA 99352, Phone (509) 372-2420; Fax (509) 376-4989.

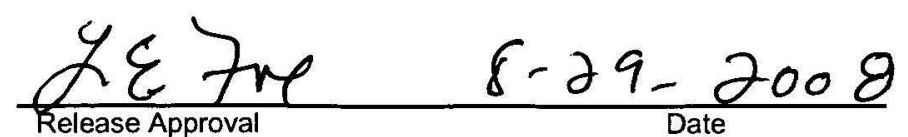

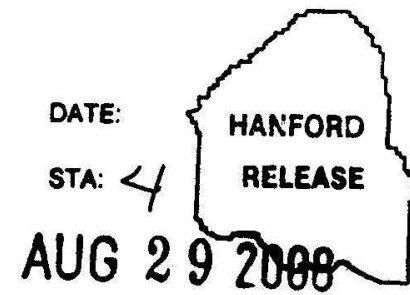

(2)

Release Stamp

\section{Approved For Public Release}


RPP-38888

Rev. 0

\title{
SPREADSHEET DESCRIPTION DOCUMENT FOR SATURATION TEMPERATURE CALCULATION
}

\author{
J. Jo \\ CH2M HILL Hanford Group, Inc.
}

Date Published

August 2008

\section{CH2MHILL}

Hanford Group, Inc.

Prepared for the U.S. Department of Energy Office of River Protection

Approved for public release; distribution unlimited 


\section{TABLE OF CONTENTS}

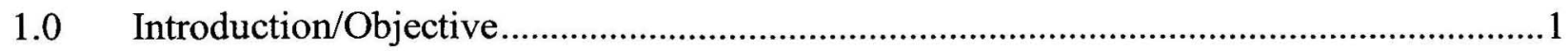

$1.1 \quad$ Saturation Temperature Spreadsheet .................................................................. 1

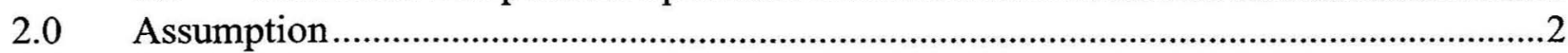

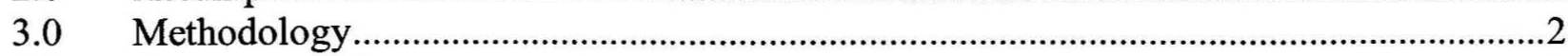

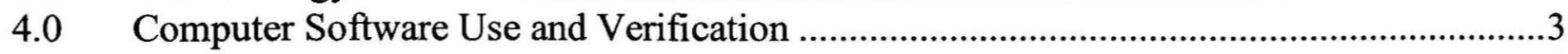

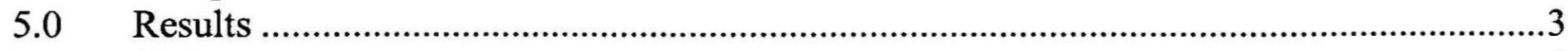

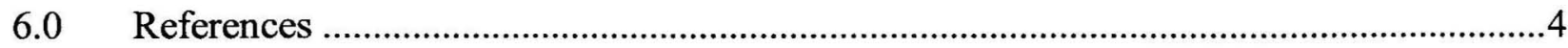


RPP-38888 Rev. 0

\section{LIST OF TERMS}

$\mathrm{Btu} / \mathrm{hr}$

In

British thermal units per hour

$\mathrm{H}_{\mathrm{CL}}$

Inch

$\rho_{\mathrm{CL}}$

$\mathrm{H}_{\mathrm{NCL}}$

$\mathrm{P}_{\mathrm{NCL}}$

$\rho_{\mathrm{NCL}}$

$\mathrm{Pa}$

psia

WCA

Height of Convective Layer (Liquid Height)

Density of Convective Layer (Liquid Density)

Height of Non-Convective Layer (Solid Height)

Pressure at midpoint of Non-Convective Layer

Density of Non-Convective Layer (Solids Density)

Pascal

pound per square inches absolute

waste compatibility assessment 


\subsection{INTRODUCTION/OBJECTIVE}

Prior to waste transfers into double shell tanks or single shell tanks, the end state of the receiving tank must be evaluated to verify that at least one of the following criteria is met.
a. Total tank heat load is $<58,000 \mathrm{Btu} / \mathrm{hr}$
OR b. Non-convective layer thickness is $<12$ in.
OR c. Supernatant depth is $<39$ in.
OR d. The non-condensable gas generation rate at saturation temperature in the non- convective layer is sufficiently low, such that the ratio of vertical void fraction profile to the neutral buoyant void fraction (buoyancy ratio) is $<1.0$ (Technical Basis for Tank Bump, RPP-6213).

If none of the criteria is met, then the waste transfer is prohibited. The first three criteria will be evaluated automatically as part of the waste compatibility assessment (WCA). If the first three criteria are not met, then further evaluation of the buoyancy ratio will be undertaken.

This document describes the methodology for determining the saturation temperature in waste tanks. The saturation temperature is used to calculate neutral buoyancy ratio.

A multiuse spreadsheet, Sat Temp.xls (henceforth, the Spreadsheet), incorporates the methodology and will be used to perform the calculation of saturation temperatures.

\subsection{Saturation Temperature Spreadsheet}

The saturation temperature spreadsheet consists of 4 worksheets as outlined in Table 1-1.

\begin{tabular}{|c|c|c|}
\hline \multicolumn{3}{|r|}{ Table 1-1 Spreadsheet Structure } \\
\hline Worksheet Title & Type & Description \\
\hline Documentation & Information & $\begin{array}{l}\text { This sheet contains the spreadsheet title, version, SVF number, } \\
\text { owner and location and the purpose of the spreadsheet. It also } \\
\text { contains a description of the methodology used and assumptions for } \\
\text { using the spreadsheet. }\end{array}$ \\
\hline Instructions & Information & Instructions for use of spreadsheet. \\
\hline ChangeLog & Information & $\begin{array}{l}\text { Change log of changes and/or corrections made to spreadsheet, } \\
\text { required by errors discovered in the spreadsheet and changes made to } \\
\text { criteria. }\end{array}$ \\
\hline Sat. Temp & $\begin{array}{l}\text { Data Input } \\
\text { Calculation }\end{array}$ & $\begin{array}{l}\text { Liquid density, liquid height, solid density, and solid height from } \\
\text { WCA are entered. Calculates adjusted pressure. User enters } \\
\text { temperatures and pressures from the steam table using adjusted } \\
\text { pressure. Saturation temperature is calculated. }\end{array}$ \\
\hline
\end{tabular}


RPP-38888 Rev. 0

\subsection{ASSUMPTION}

The following assumption is used for the spreadsheet:

- Constant ambient pressure is $1.01 \mathrm{E}+05 \mathrm{~Pa}$

\subsection{METHODOLOGY}

This section describes the spreadsheet methodology used to perform saturation temperature calculation for the non-convective layer.

- Enter liquid density, liquid height, solid density, and solid height from waste compatibility assessment.

Pressure at midpoint of Non-Convective layer is calculated, RPP-6213 (5.1.3):

$\mathrm{P}_{\mathrm{NCL}}=\mathrm{P}_{\text {ambient }}+\left(\rho_{\mathrm{CL}}\right)(\mathrm{g} / \mathrm{gc})\left(\mathrm{H}_{\mathrm{CL}}\right)+\left(\rho_{\mathrm{NCL}}\right)(\mathrm{g} / \mathrm{gc})\left(\mathrm{H}_{\mathrm{NCL}}\right) / 2$

$\mathrm{P}_{\mathrm{NCL}} \quad$ Pressure at midpoint of Non-Convective Layer

$\mathrm{H}_{\mathrm{CL}} \quad$ Height of Convective Layer (Liquid Height)

$\rho_{\mathrm{CL}} \quad$ Density of Convective Layer (Liquid Density)

$\mathrm{H}_{\mathrm{NCL}} \quad$ Height of Non-Convective Layer (Solid Height)

$\rho_{\mathrm{NCL}} \quad$ Density of Non-Convective Layer (Solids Density)

g $\quad 9.81 \mathrm{~m} / \mathrm{s}^{2}$

gc $\quad 1\left(\mathrm{~kg} \cdot \mathrm{m} / \mathrm{s}^{2)} / \mathrm{N}\right.$

- Use vapor suppression factor of 0.85 (RPP-6213 5.14) to calculate adjusted pressure:

$\mathrm{P}_{\mathrm{adj}(\mathrm{Pa})}=\mathrm{P}_{\mathrm{NCL}} / 0.85$

- Converts adjusted pressure from Pascal (Pa) to pound per square inches absolute (psia).

$\mathrm{P}_{\mathrm{adj}(\mathrm{psia})}=\mathrm{P}_{\mathrm{adj}(\mathrm{Pa})} * 14.696 / 101325$ 
- Using the calculated adjusted pressure, input saturated temperatures (T1, T2) and pressures $(\mathrm{P} 1, \mathrm{P} 2)$ from a steam table.

- Saturation temperature for waste compatibility assessment is calculated by interpolation.

$\begin{array}{ll}\mathrm{T}_{\text {sat }}=\left(\left(\mathrm{P}_{\text {adj(psia })}-\mathrm{P}_{1}\right) /\left(\mathrm{P}_{2}-\mathrm{P}_{1}\right)\right) *\left(\mathrm{~T}_{2}-\mathrm{T}_{1}\right)+\mathrm{T}_{1} \\ \mathrm{P}_{\text {adj(psia) }} & \text { Adjusted Pressure } \\ \mathrm{P}_{1} & \text { Pressure 1 } \\ \mathrm{T}_{1} & \text { Temperature 1 } \\ \mathrm{P}_{2} & \text { Pressure 2 } \\ \mathrm{T}_{2} & \text { Temperature 2 }\end{array}$

\subsection{COMPUTER SOFTWARE USE AND VERIFICATION}

Microsoft Office Excel ${ }^{\circledR}$ was used for the spreadsheet. The spreadsheet was verified in accordance with TFC-ENG-DESIGN-C-32, Revision B-6, Spreadsheet Development and Verification.

- Software and version: Microsoft ${ }^{\circledR}$ Office Excel 2003 (11.8105.8107) SP2

- File name: Sat Temp.xls

- File location: $\$ Hanford\DatalSitedata\Harmony, in the folder: V:ICompatibilitylStand Alone Evaluations|Flammable Gas EvaluationsWNeutral Buoyancy.

- File owner: J. Jo

- Spreadsheet Verification and Release Form number: SVF-1519, R0

Software name and version of any add-in software used: N/A

\subsection{RESULTS}

The Spreadsheet, Sat Temp.xls has been verified as correctly calculating saturation temperature. The methodology is described in Section 3.0 of this document and is under the assumptions in Section 2.0. 
RPP-38888 Rev. 0

\subsection{REFERENCES}

RPP-6213, 2006, Technical Basis for Tank Bump, Rev. 4, CH2M HILL Hanford Group, Inc., Richland, Washington.

TFC-ENG-DESIGN-C-32, 2006, Engineering Manual, "Spreadsheet Verification,” Rev. B-6, CH2M HILL Hanford Group, Inc., Richland, Washington.

HNF-SD-WM-OCD-015, 2008, Tank Farm Waste Transfer Compatibility Program, Rev. 18B, CH2M HILL Hanford Group, Inc., Richland, Washington. 


\begin{tabular}{|c|c|c|c|c|c|}
\hline \multicolumn{6}{|c|}{ DISTRIBUTION SHEET } \\
\hline \multirow{2}{*}{$\begin{array}{l}\text { To } \\
\text { Distribution }\end{array}$} & \multirow{2}{*}{\multicolumn{2}{|c|}{$\begin{array}{l}\text { From } \\
\text { Process Engineering }\end{array}$}} & & \multicolumn{2}{|c|}{ Page 1 of 1} \\
\hline & & & & \multicolumn{2}{|c|}{ Date $8 / 29 / 2008$} \\
\hline \multirow{2}{*}{\multicolumn{3}{|c|}{$\begin{array}{l}\text { Project Title/Work Order } \\
\text { RPP-38888, Rev. 0, Spreadsheet Description Document for Saturation } \\
\text { Temperature Calculation }\end{array}$}} & & \multicolumn{2}{|c|}{ EDT No. NA } \\
\hline & & & & \multicolumn{2}{|c|}{ ECN No. N/A } \\
\hline & MSIN & $\begin{array}{l}\text { Text } \\
\text { With All } \\
\text { Attach. }\end{array}$ & $\begin{array}{l}\text { Text } \\
\text { Only }\end{array}$ & $\begin{array}{l}\text { Attach./ } \\
\text { Appendix } \\
\text { Only }\end{array}$ & $\begin{array}{c}\text { EDT/ECN } \\
\text { Only }\end{array}$ \\
\hline
\end{tabular}

CH2M HILL Hanford Group, Inc.

W. L. Adams

J. N. Appel

T. M. Blaak

J. M. Conner

J. K. Engeman

B. K. Everett

T. L. Faust

T. G. Goetz

J. M. Grigsby

J. Jo

N. W. Kirch

M. A. Knight

D. M. Nguyen

T. C. Oten

J. H. Rasmussen

G. R. Tardiff

D. J. Washenfelder

R. A. Weber

$\begin{array}{lc}\text { S5-07 } & X \\ \text { R2-58 } & X \\ \text { S5-08 } & X \\ \text { S5-08 } & X \\ \text { S5-08 } & X \\ \text { S5-08 } & X \\ \text { S5-07 } & X \\ \text { R2-12 } & X \\ \text { S7-90 } & X \\ \text { S5-08 } & \text { HX } \\ \text { S5-08 } & X \\ \text { R2-58 } & X \\ \text { R2-12 } & X \\ \text { S5-07 } & X \\ \text { R2-12 } & X \\ \text { S5-25 } & X \\ \text { R2-58 } & X \\ \text { S5-08 } & X\end{array}$

Office of River Protection

DOE Reading Room

H2-53

$\mathrm{H}$ 